\title{
Bibliography
}

\section{Archival sources}

Archives de la Préfecture de Police de Paris (APPP)

Archives Départementales de la Haute-Garonne (Toulouse)

Archives Départementales des Bouches-du-Rhône (Marseille) (ADBR)

Archives Départementales du Rhône (Lyon)

Archives Municipales de Colombes (AMC)

Archives Municipales d'Ivry-sur-Seine (AMIS)

Archives Municipales de Lyon (AML)

Archives Municipales de Marseille (AMM)

Archives de Paris (AP)

Archives Municipales de Saint-Denis (AMSD)

Archives Municipales de Toulouse (AMT)

Archives Nationales de France (AN)

Archives Nationales de France (Fontainebleau) (ANF)

Archives of the International Olympic Committee (IOC), Lausanne, Switzerland

Fondation Le Corbusier

Forum des Images (Paris)

Institut National de l'Audiovisuel (INA)

\section{Periodicals}

L'Ami du Peuple

L'Aurore

L'Auto

L'Avant-Garde

La Croix

Daily Express 
Daily Mail / Mail on Sunday

Daily Mirror

La Dépêche

L'Echo de Paris

L'Equipe

L'Equipe Magazine

Le Figaro

Football

Football Magazine

France-Football

La Génie Civile

Le Haut Parleur: journal pratique, artistique, amusant des amis de la radio

L'Humanité

L'Illustration

L'Intransigeant

Le Journal des Sports

Libération

Lyon-Sport

Manchester Guardian / Guardian

Midi Olympique

Le Midi Sportif

Le Miroir des Sports

Le Monde

Observer

L'Oeuvre

Le Parisien

Paris-Soir

Le Petit Journal

Le Petit Marseillais

Le Petit Parisien

Le Petit Provençal

Le Progrès

Regards

Sport: La Vie en Plein Air

Sportwereld

Sud-Est Sports

Tous les Sports

La Vie au Grand Air

Yorkshire Post

92 Express: Le Magazine des Hauts-de-Seine

\section{Bulletins and government periodicals}

Allez l'O.L.: organe des amis et sympathisants de l'Olympique Lillois Annales de la Chambre des Députés 
Journal des Débats, Assemblée Nationale

Bulletin du Racing Club de France

Bulletin Municipal Officiel de la Ville de Toulouse

Bulletin Municipal Officiel de Lyon

Bulletin Municipal Officiel de Paris

Olympique Lyonnais (press releases)

\section{Primary sources}

Beaudouin, Eugène. 'Les Ensembles sportifs dans la cité. L'Architecture d'Aujourd'hui 3 (1934): 9-17.

Bénac, Gaston. Champions dans la coulisse. Paris: Actualité Sportive, 1944.

Bergvall, Erik, ed. The Official Report of the Olympic Games in Stockholm in 1912.

Translated by Edward Adams Ray. Stockholm: Wahlstrom \& Widstrand, 1913.

Comité Olympique Français. Les Jeux de la VIIIe Olympiade: rapport officiel.

Paris: Librairie de France, 1924.

Coubertin, Pierre de. Mémoires olympiques. Lausanne: Comité International Olympique, 1979.

Coubertin, Pierre de. Olympism: Selected Writings. Lausanne: International Olympic Committee, 2000.

Duhamel, Georges. Scènes de la vie future. Paris: Mercure de France, 1930.

Figuères, Léo. Jeunesse Militante: chronique d’un jeune communiste des années 3050. Paris: Editions Sociales, 1971.

Garnier, Tony. Une cité industrielle: étude pour la construction des villes. Princeton,

NJ: Architectural Press, 1989.

Goddet, Jacques. L'Equipée belle. Paris: Robert Lafont, Stock, 1991.

Herriot, Edouard. Créer. Paris: Payot et Cie, 1920.

Houston Sports Association. Inside the Astrodome: Eighth Wonder of the World!. Houston, TX: Houston Sports Association, 1965.

Howard, Ebenezer. Garden Cities of Tomorrow. London: Swan Sonnenschein \& Co. Ltd, 1902.

Imbert, José. 'Les Stades, leur architecture', L'Architecture d'Aujourd'hui 3 (1934): 18-45.

Jeanneret-Gris, Charles-Edouard [Le Corbusier]. Des canons, des munitions ... Merci! Des logis, S. V.P. Boulogne: Editions del'Architecture d'Aujourd'hui, 1938.

Jeanneret-Gris, Charles-Edouard [Le Corbusier]. The Radiant City: elements of a doctrine of urbanism to be used as the basis of our machine-age civilization. London: Faber, 1967 [1933].

Jeanneret-Gris, Charles-Edouard [Le Corbusier], and P. Jeanneret, Oeuvre complète 1934-1938 (6th edition). Zurich: Editions Girsberger, 1958.

Le Bon, Gustave. The Crowd: A Study of the Popular Mind. New York: Penguin Books, 1977.

Obey, André. L'Orgue du stade. Paris: Gallimard, 1924.

Olympia 1936: eine nationale Aufgabe. Berlin: Reichssportverlag GMBH, 1935. 
Ortega y Gasset, José. The Revolt of the Masses. New York: W. W. Norton and Company, 1932.

Pouillon, Fernand. Mémoires d'un architecte. Paris: Editions du Seuil, 1968.

Shrake, Edwin. 'Vas-y, Ja-zy! And He Went'. Sports Illustrated. 30 August 1965, pp. 32-41.

Taillibert, Roger. Construire l'avenir. Paris: Presses de la Cité, 1977.

Ville de Lyon. L'Oeuvre municipale depuis 1905. Lyon: Ville de Lyon, 1952.

\section{Secondary sources}

Arnaud, Pierre. Le Militaire, lécolier, le gymnaste: naissance de l'éducation physique en France, 1869-1889. Lyon: Presses Universitaires de Lyon, 1991.

Bacqué, Marie-Hélène, and Sylvie Fol. Le Devenir des banlieues rouges. Paris: Editions Harmattan, 1997.

Bacqué, Marie-Hélène. 'Le Stade de France à Saint-Denis: grands équipements et développement urbain'. Les Annales de la Recherche Urbaine 79 (1998): 126-33.

Bale, John. Sport, Space and the City. London and New York: Routledge, 1993.

Barrows, Susanna. Distorting Mirrors: Visions of the Crowd in Late 19th-Century France. New Haven, CT, and London: Yale University Press, 1981.

Bastié, Jean. Nouvelle Histoire de Paris: Paris de 1945 à 200o. Paris: Association pour la Publication d'une Histoire de Paris/Diffusion Hachette, 2001.

Beaudet, Hubert. La Coupe de France: ses vainqueurs, ses surprises. Saint-Cyr-surLoire: Editions Alan Sutton, 2003.

Bellanger, Claude, Jacques Godechot, Pierre Guiral and Fernand Terrou. Histoire générale de la presse française (Volume 3: 1871-1940). Paris: Presses Universitaires de France, 1972.

Ben-Amos, Avner. Funerals, Politics, and Memory in Modern France, 1789-1996. Oxford: Oxford University Press, 2000.

Bess, Michael. The Light-Green Society: Ecology and Technological Modernity in France, 1960-2000. Chicago, IL: University of Chicago Press, 2003.

Bolz, Daphne. Les Arènes totalitaires: Hitler, Mussolini et les jeux du stade. Paris: Editions CNRS, 2008.

Bosworth, R. J. B. Mussolini's Italy. New York: Penguin, 2007.

Boury, Paul. La France du Tour: le Tour de France, un espace sportif à géographie variable. Paris: L'Harmattan, 1997.

Bovet, Philippe. 'Les Riches Heures du stade Buffalo'. 92 Express: Le Magazine des Hauts-de-Seine 61 (1995): 30-6.

Bromberger, Christian. Football, la bagatelle la plus sérieuse du monde. Paris: Bayard Editions, 1998.

Bromberger, Christian. 'Le Sport et ses publics'. In Pierre Arnaud, Michael Attali and Jean Saint-Martin, eds, Le Sport en France: une approche politique, économique, et sociale. Paris: Documentation Française, 2008, pp. 113-34.

Bromberger, Christian. 'LOOM, un club au diapason de sa ville'. Marseille: Revue Culturelle 184 (1998): 97-107. 
Bromberger, Christian, Alain Hayot and Jean-Marc Mariottini. Le Match de football: ethnologie d'une passion partisane à Marseille, Naples et Turin. Paris: Editions de la Maison des Sciences de l'homme, 1995.

Brunet, Jean-Paul. Police contre FLN: le drame d'octobre 1961. Paris: Flammarion, 1999.

Brunet, Jean-Paul. Saint-Denis la ville rouge: socialisme et communisme en banlieue ouvrière, 1890-1939. Paris: Hachette, 1980.

Burrin, Philippe. La Dérive Fasciste: Doriot, Déat, Bergery, 1933-1945. Paris: Seuil, 2003.

Burrin, Philippe. 'Poings levés et bras tendus: la contagion des symboles au temps du Front Populaire'. Vingtième Siècle 11 (1986): 5-20.

Callède, Jean-Paul. Histoire du sport en France du Stade Bordelais au S.B.U.C. Bordeaux: Editions de la Maison des Sciences de l'Homme d'Aquitaine, 1993.

Callède, Jean-Paul. 'Les Journalistes de sport en France: une profession qui souvre aux femmes?'. In Jean-Paul Callède, ed., Le Journaliste et le sport: responsable(s) ou otage(s). Pessac: Maison des Sciences de l'Homme d'Aquitaine, 2006, pp. 161-90.

Callède, Jean-Paul. Les Politiques sportives en France: éléments de sociologie historique. Paris: Economica, 2000.

Carpentier-Bogaert, Catherine, et al. Le Peuple des tribunes: les supporters de football dans le Nord-Pas-de-Calais. Béthune: Musée d'Ethnologie Régionale, 1998.

Carrier, Peter. Holocaust Monuments and National Memory Cultures in France and Germany Since 1989. New York: Berghahn Books, 2005.

Cazal, Jean-Michel, et al. L'Intégrale de l'équipe de France de Football. Paris: Editions First, 1998.

Certeau, Michel de. The Practice of Everyday Life. Translated by Steven Rendall. Berkeley: University of California Press, 1984.

Chaix, Pierre. Le Rugby professionel en France: enjeux économiques et sociaux. Paris: L'Harmattan, 2004.

Chany, Pierre, and Thierry Cazeneuve. La Fabuleuse Histoire du Tour de France. Geneva: Editions Minerva, 2004.

Chartier, Roger. 'Les deux Frances: histoire d'une géographie.. Cahiers d'Histoire 23 (4) (1978): 393-415.

Chazaud, Pierre. 'Le Sport et les medias au XXe siècle: de la culture de masse à la médiatisation du sport'. In Pierre Arnaud, ed., Le Sport en France: une approche politique, économique et sociale. Paris: Documentation Française, 2000. pp. 138-42.

Coeuré, Sophie. La Grande Lueur à l'est: les Français et l'Union Soviétique. Paris: Seuil, 1999.

Cogoluenhes, Henri. 'Au stade municipal de Gerland'. Rive Gauche 144 (1998): 3-11. Collard, Susan. 'Politics, Culture and Urban Transformation in Jacques Chirac's Paris, 1977-1995'. French Cultural Studies 7 (19) (1996): 1-31.

Combeau, Yvan, and Philippe Nivet. Histoire politique de Paris au XXe siècle: une histoire locale et nationale. Paris: Presses Universitaires de France, 2000. 
Corbin, Alain, Noëlle Gérôme and Danielle Tartakowsky, eds. Les Usages politiques des fêtes aux XIXe-XXe siècles. Paris: Publications de la Sorbonne, 1994.

Coustet, Robert. 'Le Stade municipal et le Parc des Sports de Bordeaux: recherche de la Paternité. Revue Historique de Bordeaux et du Département de la Gironde (1982): 149-65.

Cunningham, Hugh. Leisure and the Industrial Revolution, c. 1780-1880. London: Croom Helm, 1980.

Daniels, Stephen, and Denis Cosgrove. 'Spectacle and Text: Landscape Metaphors in Cultural Geography'. In James Duncan and David Ley, eds, Place/Culture/ Representation. New York and London: Routledge, 1993, pp. 57-77.

Darby, Paul. Africa, Football and FIFA: Politics, Colonialism and Resistance. London: Frank Cass, 2002.

Dauncey, Hugh. 'Building the Finals: Facilities and Infrastructure'. In Hugh Dauncey and Geoff Hare, eds, France and the 1998 World Cup: The National Impact of a World Sporting Event. London: Frank Cass, 1999, pp. 98-120.

Dauncey, Hugh, and Geoff Hare, eds. France and the 1998 World Cup: The National Impact of a World Sporting Event. London: Frank Cass, 1999.

Dauncey, Hugh, and Geoff Hare, eds. The Tour de France, 1903-2003: A Century of Sporting Structures, Meanings and Values. London: Frank Cass, 2003.

De Grazia, Victoria. The Culture of Consent: Mass Organization of Leisure in Fascist Italy. Cambridge: Cambridge University Press, 1981.

Delépine, Michaël. 'The Racing Club vs. Arsenal Matches (1930-1962): A FrancoBritish Ritual, European Games or Football Lessons?' Sport in History 35 (4) (December 2015): 604-17.

Delépine, Michaël. Les Stades du football français. Paris: Alan Sutton Eds, 2010.

Derlon, Alain. Sport, nationalisme français et régénération de la 'race': 1880-1914. Paris: L'Harmattan, 2008.

Dickson, Andy. Du Vél' d'Hiv' au Palais ... des sports et des arts. Biarritz: Editions Atlantica, 1999.

Dietschy, Paul. 'Les Matchs du Stadio Mussolini: sport, football, et politique à Turin sous le fascisme'. Cahiers d'Histoire 38 (2) (1993): 153-74.

Dine, Philip. French Rugby Football: A Cultural History. Oxford: Berg, 2001.

Drocourt, Daniel. 'Le Stade-Vélodrome de Marseille, deuxième stade de France'. Marseille: Revue Culturelle 184 (1998): 69-75.

Dubois, Laurent. Soccer Empire: The World Cup and the Future of France. Berkeley: University of California Press, 2010.

Dunning, Eric, Patrick Murphy and John Williams. The Roots of Football Hooliganism: An Historical and Sociological Study. London: Routledge and Kegan Paul Ltd, 1988.

Dutton, Paul V. Origins of the French Welfare State: The Struggle for Social Reform in France, 1914-1947. Cambridge and New York: Cambridge University Press, 2002.

Elias, Norbert, and Eric Dunning. The Quest for Excitement: Sport and Leisure in the Civilizing Process. Oxford and New York: Basil Blackwell, 1986. 
Ensalaco, Mark. Chile Under Pinochet: Recovering the Truth. Philadelphia: University of Pennsylvania Press, 2000.

Falasca-Zamponi, Simonetta. Fascist Spectacle: The Aesthetics of Power in Mussolini's Italy. Berkeley: University of California Press, 1997.

Faure, Christian. Le Project culturel de Vichy: folklore et révolution nationale 19401944. Lyon: Presses Universitaires de Lyon, 1989.

Fierro, Annette. The Glass State: The Technology of the Spectacle, Paris 1981-1998. Cambridge, MA: MIT Press, 2001.

Fishwick, Nicholas. English Football and Society, 1910-1950. Manchester and New York: Manchester University Press, 1989.

Foer, Franklin. How Soccer Explains the World: An Unlikely Theory of Globalization. New York: Harper Collins, 2004.

Fontaine, Marion. Le Racing Club de Lens et les 'gueules noires': essai d'histoire sociale. Paris: Les Indes Savantes, 2010.

Ford, Caroline. Creating the Nation in Provincial France: Religion and Political Identity in Brittany. Princeton, NJ: Princeton University Press, 1993.

Foucault, Michel. Discipline and Punish: The Birth of the Prison. Translated by Alan Sheridan. New York: Vintage Books, 1977.

Fourcault, Annie. Bobigny, banlieue rouge. Paris: Les Editions Ouvrières/Presses de la Fondation Nationale des Sciences Politiques, 1986.

Fourastié, Jean. Les Trente Glorieuses, ou la révolution invisible de 1946 à 1975. Paris: Fayard, 1979.

Frank, Sybille, and Silke Steets, eds. Stadium Worlds: Football, Space and the Built Environment. Abingdon: Routledge, 2010.

Gaffney, Christopher. Temples of the Earthbound Gods: Stadiums in the Cultural Landscapes of Rio de Janeiro and Buenos Aires. Austin: University of Texas Press, 2008.

Gaudin, Henri, and Bruno Gaudin. Le Stade Charléty. Paris: Les Editions du Demi-Cercle, 1994.

Gay-Lescot, Jean-Louis. Sport et éducation sous Vichy, 1940-1944. Lyon: Presses Universitaires de Lyon, 1991.

Gentile, Emilio. The Sacralization of Politics in Fascist Italy. Cambridge, MA, and London: Harvard University Press, 1996.

Gérôme, Noëlle, and Danielle Tartakowsky. La Fête de L'Humanité: culture communiste, culture populaire. Paris: Messidor/Editions Sociales, 1988.

Gibson, Robert. Best of Enemies: Anglo-French Relations Since the Norman Conquest. Exeter: Impress Books, 2004.

Gravelaine, Frédérique de. Le Stade de France: au coeur de la ville, pour le sport et le spectacle. L'Histoire d'une aventure architecturale et humaine. Paris: Le Moniteur, 1997.

Guttmann, Allen. The Olympics: A History of the Modern Games. Champaign: University of Illinois Press, 1992.

Haegel, Florence. Un maire à Paris: mise en scène d'un nouveau rôle politique. Paris: Presses de la Fondation Nationale des Sciences Politiques, 1994. 
Hare, Geoff. Football in France: A Cultural History. Oxford: Berg, 2003.

Harp, Stephen L. Marketing Michelin: Advertising and Cultural Identity in Twentieth-

Century France. Baltimore, MD: The Johns Hopkins University Press, 2001.

Hart-Davis, Duff. Hitler's Games. New York: Harper and Row, 1986.

Hecht, Gabrielle. The Radiance of France: Nuclear Power and National Identity after World War II. Cambridge, MA: MIT Press, 1998.

Hervaux, Yves. Le Paris d'un maire: 1977-1995: la métamorphose. Paris: Albin Michel, 1995.

Hobsbawm, Eric, and Terence Ranger, eds. The Invention of Tradition. Cambridge: Cambridge University Press, 1992.

Holt, Richard. Sport and Society in Modern France. Hamden, CT: Archon Books, 1981.

Howell, Paul Charles. The Montreal Olympics: An Insider's View of Organizing a Self-Financing Games. Montreal and Kingston: McGill-Queen's University Press, 2009.

Hubscher, Ronald, ed. L'Histoire en mouvements: le sport dans la société française (XIXe-XXe siècle). Paris: Armand Colin Editeur, 1992.

Jackson, Julian. The Popular Front in France Defending Democracy, 1934-38. Cambridge: Cambridge University Press, 1988.

Jaeger, Falk, ed. Next 3 Stadia: Warsaw, Bucharest, Kiev. Berlin: Jovis Verlag $\mathrm{GmbH}, 2 \mathrm{O12}$.

Jay, Martin. Downcast Eyes: The Denigration of Vision in 2oth-Century French Thought. Berkeley: University of California Press, 1993.

Jennings, Eric. Vichy in the Tropics: Pétain's National Revolution in Madagascar, Guadeloupe and Indochina, 1940-1944. Stanford, CA: Stanford University Press, 2001.

Jensen, Erik. Body by Weimar: Athletes, Gender and German Modernity. Oxford: Oxford University Press, 2007.

Jobs, Richard Ivan. Riding the New Wave: Youth and the Rejuvenation of France after the Second World War. Stanford, CA: Stanford University Press, 2007.

Kéchichian, Albert. Les Croix-de-feu à l'âge des fascismes: travail, famille, patrie. Paris: Seyssel/Presses Universitaires de France, 2006.

King, Anthony. 'The New European Stadium'. In Sybille Frank and Silke Steets, eds, Stadium Worlds: Football, Space and the Built Environment. Abingdon: Routledge, 2010, pp. 19-35.

Kennedy, Sean. Reconciling France against Democracy: The Croix de Feu and the Parti Social Français, 1927-1945. Montreal: McGill-Queen's University Press, 2007.

Köhring, Alexandra. “'Sporting Moscow”: Stadia Buildings and the Challenging of Public Space in the Post-War Soviet Union'. Urban History 37 (2) (2010): 253-71.

Koshar, Rudy. German Travel Cultures. Oxford: Berg, 2000.

Krüger, Arnd, and William Murray, eds. The Nazi Olympics: Sport, Politics, and Appeasement in the 1930s. Urbana: University of Illinois Press, 2003.

Kuisel, Richard. Seducing the French: The Dilemma of Americanization. Berkeley: University of California Press, 1993. 
Lacouture, Jean. Pierre Mendès France. Paris: Seuil, 1981.

Lafond, Pierre, and Jean-Pierre Bodis. Encyclopédie du rugby français. Paris: Editions Dehedin, 1989.

Lane, Barbara Miller. Architecture and Politics in Germany, 1918-1945. Cambridge, MA: Harvard University Press, 1968.

Lefebvre, Henri. The Production of Space. Cambridge, MA: Blackwell, 1991.

Leith, James. Space and Revolution: Projects of Monuments, Squares and Public Buildings in France, 1789-1799. Montreal and Kingston: McGill-Queen's University Press, 1991.

Lempa, Heikki. Beyond the Gymnasium: Educating the Middle-Class Bodies in Classical Germany. Lanham, MD: Lexington Books, 2007.

Leroy, Pascal. Un siècle de sport cycliste dans les Hauts-de-Seine. Nanterre: Conseil Général des Hauts-de-Seine, 2003.

Leroy, Pascal. 'La Belle Histoire des enfants de l'ovalie'. 92 Express: Le Magazine des Hauts-de-Seine 45 (2003): 60-5.

Leroy, Pascal. 'Le Grand Stade de Le Corbusier'. 92 Express: Le Magazine des Hauts-de-Seine 95 (1998): 66-7.

Leroy, Pascal. 'Le Roman-feuilleton du grand stade'. L'Equipe Magazine 824, 24 January 1998.

Lévy, Claude, and Paul Tillard. La Grande Rafle du Vél' d'Hiv' (16 juillet 1942). Paris: Robert Laffont, 1992.

Loubet, Jean-Louis. Histoire de l'automobile française. Paris: Editions du Seuil, 2001.

Lucan, Jacques, ed. Fernand Pouillon architecte: Pantin Montrouge BoulougneBillancourt Meudon-la-Fôret. Paris: Editions du Pavillion de l'Arsenal, 2003.

Mallet-Stevens, Robert. Robert Mallet-Stevens: l'oeuvre complète. Paris: Editions du Centre Pompidou, 2005.

Mangan, J. A. "Muscular, Militaristic and Manly": The British Middle-Class Hero as Moral Messenger'. The International Journal of the History of Sport 13 (1) (1996): 28-47.

Marchand, Jacques. Jacques Goddet journaliste d'abord: quarante ans à la tête d'un quotidien sportif et du Tour de France. Biarritz: Atlantica, 2002.

Martin, Benjamin F. France and the Après-Guerre, 1918-1924: Illusions and Disillusionment. Baton Rouge: Louisiana State University Press, 1999.

Marrus, Michael, and Robert O. Paxton. Vichy France and the Jews. Stanford, CA: Stanford University Press, 1995.

Mason, Anthony. Association Football and English Society, 1863-1915. Brighton: Harvester Press, 1980.

Massey, Doreen. Space, Place and Gender. Minneapolis: University of Minnesota Press, 1994.

Mauroy, Pierre. Léo Lagrange. Paris: Denoël, 1997.

Mignon, Patrick. La Passion du football. Paris: Odile Jacob, 1998.

Mosse, George. The Image of Man. New York: Oxford University Press, 1996.

Mosse, George. The Nationalization of the Masses: Political Symbolism and Mass Movements in Germany from the Napoleonic Wars Through the Third Reich. New York: Howard Fertig, 1975. 
Muel-Dreyfus, Francine. Vichy and the Eternal Feminine. Translated by Kathleen A. Johnson. Durham, NC: Duke University Press, 2001.

Nagai, Nobuhito. Les Conseillers municipaux de Paris sous la IIIe République (1871-1914). Paris: Publications de la Sorbonne, 2002.

Newman, Peter, and Melanie Tual. 'The Stade de France: The Last Expression of French Centralism?'. European Planning Studies 10 (7) (2002): 831-43.

Noiriel, Gérard. The French Melting Pot: Immigration, Citizenship and National Identity. Translated by Geoffroy de Laforcade. Minneapolis: University of Minnesota Press, 1996.

Nord, Philip. France's New Deal: From the Thirties to the Postwar Era. Princeton, NJ: Princeton University Press, 2010.

Nivet, Philippe. Le Conseil municipal de Paris de 1944 à 1977. Paris: Publications de la Sorbonne, 1994.

Nye, David E. American Technological Sublime. Cambridge, MA, and London: MIT Press, 1994.

Ory, Pascal. La Belle Illusion: culture et politique sous le signe du Front Populaire, 1935-1938. Paris: Plon, 1994.

Ory, Pascal. Une nation pour mémoire: 1889, 1939, 1989 trois jubilés révolutionnaires. Paris: Presses de la Fondation Nationale des Sciences Politiques, 1992.

Ozouf, Mona. La Fête révolutionnaire 1789-1799. Paris: Gallimard, 1976.

Pawlowski, Christophe. Tony Garnier et les débuts de l'urbanisme fonctionnel en France. Paris: Publications du Centre de Recherche d'Urbanisme (CRU), 1967.

Paxton, Robert. Vichy France: Old Guard and New Order, 1940-1944. New York: Columbia University Press, 1972.

Petrone, Karen. Life has Become More Joyous, Comrades: Celebrations in the Time of Stalin. Bloomington: University of Indiana Press, 2000.

Pérouas, Louis. 'Le Grand Retour de Notre-Dame de Boulogne à travers la France (1943-1948): essai de reconstitution'. Annales de Bretagne et des Pays de l'Ouest 90 (1983): 171-83.

Phillips, Peggy. Modern France: Theories and Realities of Urban Planning. Landham, MD: University Press of America, 1987.

Pizzori-Itié, Florence, ed. Les Yeux du stade: Colombes, Temple du Sport. Colombes: Editions de l'Albaron, Musée Municipal d'Art et d'Histoire de Colombes, 1993.

Poletti, Mattéo. Colombes historique (faits, documents, images et personages): des origines à la fin de la Seconde Guerre mondiale. Colombes: MJC, 1984.

Polo, Jean-François. 'A côté du Tour: Ambushing the Tour for Political and Social Causes'. In Hugh Dauncey and Geoff Hare, eds, The Tour de France, 19032003: A Century of Sporting Structures, Meanings and Values. London: Frank Cass, 2003, pp. 246-66.

Prochasson, Christophe, and Anne Rasmussen. Au nom de la patrie: les intellectuels et la première guerre mondiale, 1910-1919. Paris: Editions la Découverte, 1996.

Pronier, Raymond. Les Municipalités communistes. Paris: Balland, 1983.

Pulju, Rebecca. Women and Mass Consumer Society in Postwar France. Cambridge and New York: Cambridge University Press, 2011. 
Ranc, David. 'Local Politics, Identity and Football in Paris'. Modern \& Contemporary France 17 (1) (2009): 51-65.

Rauch, André. Les Vacances. Paris: Presses Universitaires de France, 1993.

Reed, Eric. 'The Economics of the Tour, 1930-200o'. In Hugh Dauncey and Geoff Hare, eds, The Tour de France, 1903-2003: A Century of Sporting Structures, Meanings and Values. London: Frank Cass, 2003, pp. 103-27.

Reed, Eric. Selling the Yellow Jersey: The Tour de France in a Global Era. Chicago,

IL: University of Chicago Press, 2015.

Reed, Eric. 'The Tour de France in the Provinces: Mass Culture and Provincial Communities' Relations with the Broader World'. French Historical Studies 30 (4) (2007): 623-49.

Reichel, Peter. 'Festival and Cult: Masculine and Militaristic Mechanisms of National Socialism. In J. A. Mangan, ed., Shaping the Superman: Fascist Body as Political Icon in Aryan Fascism. London: Frank Cass, 1999, pp. 153-68.

Reichel, Peter. Der schöne Schein des Dritten Reiches: Faszination und Gewalt des Fachismus. Munich: Hanser, 1991.

Remplon, Lucien. Ombres noires et soleils rouges: histoire du rugby au Stade Toulousain. Toulouse: Editions Gazette, 1998.

Renaud, Jean-Pierre. Paris, un état dans l'état. Paris: Editions l'Harmattan, 1993.

Rivoire, Xavier. Stades de Légende: 50 enceintes mythiques du football européen. Paris: SOLAR, 2002.

Roberts, Mary Louise. Civilization Without Sexes: Reconstructing Gender in Postwar France, 1917-1927. Chicago, IL: University of Chicago Press, 1994.

Roche, Maurice. Mega-Events and Modernity: Olympics and Expos in the Growth of Global Culture. London and New York: Routledge, 2000.

Roncayolo, Marcel, et al., eds. La Ville aujourd'hui: mutations urbaines, décentralisation et crise du citadin. Paris: Editions de Seuil, 1985/2001.

Rossol, Nadine. Performing the Nation in Interwar Germany: Sport, Spectacle and Political Symbolism, 1926-36. Basingstoke and New York: Palgrave Macmillan, 2010.

Rousso, Henry. The Vichy Syndrome: History and Memory in France Since 1944. Cambridge, MA: Harvard University Press, 1991.

Schiller, Kay, and Christopher Young. The 1972 Munich Olympics and the Making of Modern Germany. Berkeley: University of California Press, 2010.

Schmidt, Vivien A. 'French Capitalism Transformed, Yet Still a Third Variety of Capitalism'. Economy and Society 32 (4) (2003): 526-54.

Schor, Ralph. L'Opinion française et les étrangers en France, 1919-1939. Paris: Publications de la Sorbonne, 1985.

Schwartz, Vanessa R. Spectacular Realities: Early Mass Culture in Fin-de-Siècle Paris. Berkeley: University of California Press, 1998.

Searle, Glen. 'Uncertain Legacy: Sydney's Olympic Stadiums'. European Planning Studies 10 (7) (2002): 845-60.

Seidler, Edouard. Le Sport et la presse. Paris: Armand Colin, 1964.

Senn, Alfred. Power, Politics and the Olympics Games. Champaign, IL: Human Kinetics, 1999. 
Sheard, Rod. The Stadium: Architecture for the New Global Culture. Singapore: Periplus, 2005.

Sherman, Daniel. The Construction of Memory in Interwar France. Chicago, IL: University of Chicago Press, 1999.

Shorrock, William. From Ally to Enemy: The Enigma of Fascist Italy in French Diplomacy, 1920-1940. Kent, OH: Kent State University Press, 1988.

Strauss, Léon. 'Le Sport travailliste français pendant l'entre-deux-guerres'. In Pierre Arnaud, ed., Les Origines du sport ouvrier en Europe. Paris: Editions L'Harmattan, 1994, pp. 193-218.

Sutcliffe, Anthony. Towards the Planned City: Germany, Britain, the United States and France, 1780-1914. New York: St Martin's Press, 1981.

Taillibert, Roger, and Alain Orlandini. Roger Taillibert: réalisations. Paris: Somogy, 2004.

Taillibert, Roger, and Marc Emery. Roger Taillibert: Architecte = Architect . Montreal: Editions Hurtubise HMH, 1976.

Tartakowsky, Danielle. Les Manifestations de rue en France, 1918-1968. Paris: Publications de la Sorbonne, 1997.

Tartakowsky, Danielle. 'Manifestations, fêtes et rassemblements à Paris, Juin 1936- Novembre 1938'. Vingtième Siècle 27 (1990): 50-65.

Taylor, Matthew. The Association Game: A History of British Football. Harlow: Pearson Education Ltd, 2008.

Thiesse, Anne-Marie. Ils apprenaient la France: l'exaltation des régions dans le discours patriotique. Paris: Editions de la Maison des Sciences de l'Homme, 1997.

Thompson, Christopher. The Tour de France: A Cultural History. Berkeley: University of California Press, 2006.

Trumpbour, Robert. The New Cathedrals: Politics and Media in the History of Stadium Construction. Syracuse, NY: Syracuse University Press, 2007.

Tumblety, Joan. 'The Soccer World Cup of 1938'. French Historical Studies 31 (1) (2008): 77-116.

Urry, John. Sociology Beyond Societies: Mobilities for the Twenty-First Century. London and New York: Routledge, 2000.

Vigarello, Georges. 'Le Tour de France'. In Pierre Nora, ed., Les Lieux de mémoire III: Les France (Volume 2). Paris: Gallimard, 1992, pp. 883-925.

Wahl, Alfred. Les Archives du football: sport et société en France, 1880-1989. Paris: Editions Gallimard/Juilliard, 1989.

Wahl, Alfred, and Pierre Lanfranchi. Les Footballeurs professionnels des années trente à nos jours. Paris: Hachette, 1995.

Wakeman, Rosemary. The Heroic City: Paris, 1945-1958. Chicago, IL: University of Chicago Press, 2009.

Wakeman, Rosemary. Modernizing the Provincial City: Toulouse, 1945-1975. Cambridge, MA, and London: Harvard University Press, 1997.

Wakeman, Rosemary. 'Nostalgic Modernism and the Invention of Paris'. French Historical Studies 27 (1) (2004): 116-43. 
Walton, John K. 'Reconstructing Crowds: The Rise of Association Football as a Spectator Sport in San Sebastian, 1915-32'. The International Journal of the History of Sport 15 (1) (1998): 27-53.

Wardhaugh, Jessica. In Pursuit of the People: Political Culture in France, 1934-39. Basingstoke and New York: Palgrave MacMillan, 2009.

Weitz, Eric. Creating German Communism, 1890-199o: From Popular Protests to Socialist State. Princeton, NJ: Princeton University Press, 1997.

Wharton, Steve. Screening Reality: French Documentary Under German Occupation. Bern: Peter Lang AG, 2006.

Whitney, Susan B. 'Gender, Class, and Generation in Interwar French Catholicism: The Case of the Jeunesse Ouvrière Chrétienne Féminine'. Journal of Family History 26 (2001): 480-507.

Whitney, Susan. Mobilizing Youth: Communists and Catholics in Interwar France. Durham, NC: Duke University Press, 2009.

Young, Patrick. Enacting Brittany: Tourism and Culture in Provincial France, 1871-1939. Farnham: Ashgate, 2012.

Young, Patrick. 'La Vieille France as Object of Bourgeois Desire: The TouringClub de France and the French Regions, 1890-1918'. In Rudy Koshar, ed., Histories of Leisure. Oxford: Berg, 2002, pp. 169-90

\section{Internet sources}

Courmont, Barthélémy. 'L'Inquiétante américanisation de la vie politique française'. Centre d'Etudes Transatlantiques. 17 January 2007. Available at: www. centretransatlantique.fr/pdf/bct1.pdf (accessed 7 July 2008).

Website for the planned rugby grand stade: Grandstaderugby.fr (accessed 24 October 2015).

\section{Unpublished sources}

Bobet, Guillaume. 'Le Public et le spectacle sportif dans les stades de football en France, 1918-1998: les incidents du 29 décembre 1929 au stade Buffalo de Montrouge'. Master 2 thesis, Université Panthéon-Sorbonne-Paris 1, 2009.

Lê-Germain, Elisabeth. 'La Politique sportive de la ville de Lyon au temps d'Edouard Herriot (1905-1957)'. PhD dissertation, Université ClaudeBernard-Lyon 1, 2001.

Kssis, Nicolas. 'La Municipalité ouvrière et le milieu sportif: tutelle ou complementarité. Paper presented at 'Les Associations et le champ politique au XXe siècle' conference at the Sénat in Paris, Salle Clemenceau, 16-17 November 2000.

Rab, Sylvie. 'Culture et banlieue: les politiques culturelles dans les municipalités de la Seine (1935-1939)'. PhD dissertation, Université de Paris Diderot-Paris 7, 1994. 
Thompson, Christopher. 'The Third Republic on Wheels: A Social, Cultural and Political History of Bicycling in France from the 19th Century to World War II'. PhD dissertation, New York University, 1995.

\section{Interviews}

Author interview with Andy Dickson in Paris, 17 June 2008. 